\title{
The Effects of Horses and Raiding on the Salt Industry in Northwest Louisiana
}

Paul N. Eubanks

Middle Tennessee State University

Follow this and additional works at: https://scholarworks.sfasu.edu/ita

Part of the American Material Culture Commons, Archaeological Anthropology Commons, Environmental Studies Commons, Other American Studies Commons, Other Arts and Humanities Commons, Other History of Art, Architecture, and Archaeology Commons, and the United States History Commons

Tell us how this article helped you.

This Article is brought to you for free and open access by the Center for Regional Heritage Research at SFA ScholarWorks. It has been accepted for inclusion in Index of Texas Archaeology: Open Access Gray Literature from the Lone Star State by an authorized editor of SFA ScholarWorks. For more information, please contact cdsscholarworks@sfasu.edu. 


\section{The Effects of Horses and Raiding on the Salt Industry in Northwest Louisiana Creative Commons License \\ (c) $(1)(9)$}

This work is licensed under a Creative Commons Attribution-NonCommercial 4.0 International License 


\title{
The Effects of Horses and Raiding on the Salt Industry in Northwest Louisiana
}

\author{
Paul N. Eubanks \\ Middle Tennessee State University
}

When French explorers first arrived in northwest Louisiana, the local Caddo Indians had already earned a reputation for being important players in the salt trade. Likewise, many western Caddo groups living near the southern Plains were known for their involvement in the horse trade. In the first part of this paper, the relationship between the local salt industry and the introduction of the horse is considered. It is suggested that at least some of the salt made in northwest Louisiana was being fed to horses and other livestock acquired either directly or indirectly from the Spanish. In addition to its potential effect on the salt trade, the introduction of the horse in the southern Plains also spurred an increase in theft and raiding. Historical data suggest that Caddo salt producers may have been worried about such activities from hostile groups like the Osage and Chickasaw. In the second part of this paper, it is argued that these Caddos may have tried to discourage raiding by using salt licks bordered by waterways, by working in close proximity to other salt producers, and by traveling long distances to reach wellprotected salt production sites.

\section{Introduction}

By the early eighteenth-century the Caddo Indians of northwest Louisiana were well known for their prominent role in the salt trade. However, this reputation may have been earned as recently as the protohistoric period, since there is little evidence of large-scale salt production in this region prior to A.D. 1600 (Eubanks and Brown 2015) ${ }^{1}$. The relatively late onset of salt making in northwest Louisiana is generally out of step with the rest of the Southeast. For instance, in southern Illinois there is evidence for pre-Mississippian salt manufacture beginning sometime between A.D. 750 and A.D. 900, and at salines in southern Alabama and southeastern Missouri there is also evidence for Woodland-period salt production (Dumas 2007; Keslin 1964; Muller 1984). Likewise, in other parts of the Caddo Homeland such as southern Arkansas and eastern Texas, salt making appears to have started sometime around the fourteenth century (Early 1993; Kenmotsu 2005).

In much of eastern North America and throughout the world in general, there is a connection between the beginning of salt production and the rise of agriculture. This is because most plant-based foods, including maize, are naturally low in sodium chloride, a mineral which is necessary for human survival (Brown 1980:4; 2004). Although the late prehistoric Caddo were consuming some low-sodium foods like maize, in northwest Louisiana it seems doubtful that a dietary need for salt resulting from agriculture alone could account for the beginning of salt making, since there is little evidence that salt was made in this region prior to the protohistoric period (Eubanks 2016:231-232). Thus, while maize appears to have been a common source of food in late prehistoric northwest Louisiana, so too was meat, especially from deer and fish (Kelley 2012:427-429). These animal-based foods, which are rich in sodium, seem to have made it unnecessary for the late prehistoric Caddo in this region to supplement their maize-heavy diets with additional salt.

Elsewhere, I have argued that the local environment and the presence of nearby European traders played important roles in helping to drive the Caddo salt trade in northwest Louisiana (Eubanks 2014). However, it is suggested here that other factors such as raiding and the introduction of the horse also had an impact on the salt trade. This latter topic is the subject of the first part of this paper while the issue of raiding will be dealt with in subsequent sections. While current data do not permit any firm conclusions to be drawn, the following hypotheses are presented:

1. At least some of the salt made in northwest Louisiana found its way into the hands of people who were feeding it to horses and other livestock.

2. Raiding would have been a concern for the individuals involved in the production and trade of salt in northwest Louisiana during the protohistoric and early historic periods. 


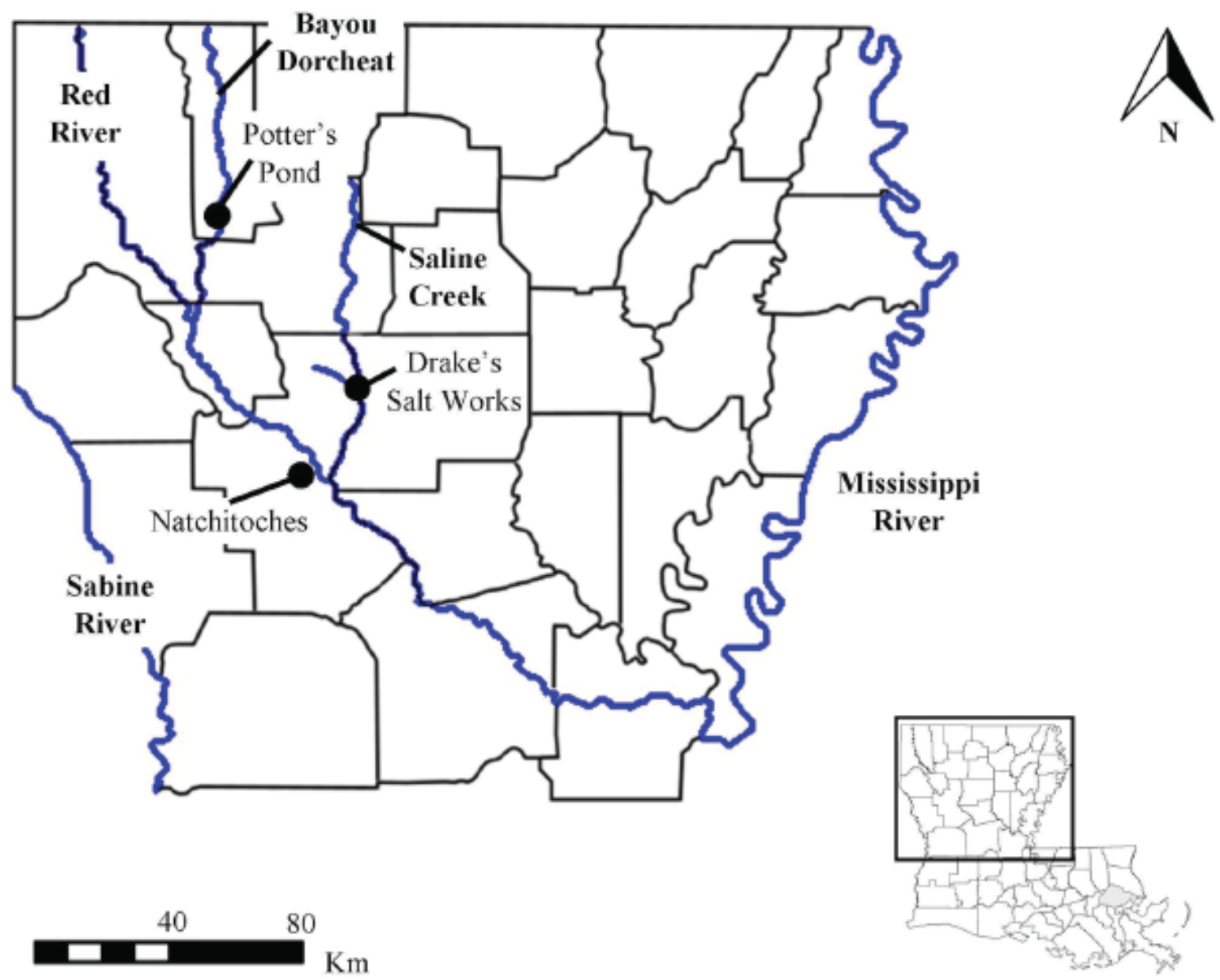

Figure 1. Northern Louisiana with the locations of sites and waterways mentioned in this article.

\section{Major Salt Licks in Northwest Louisiana}

Much of the contact-era salt production industry in northwest Louisiana occurred roughly $30 \mathrm{~km}$ (18 miles) northeast of present-day Natchitoches at the Drake's Salt Works Site Complex (Figure 1). In addition to being the most intensively utilized salt production locale in northwest Louisiana, this saline also played a key role in helping to facilitate trade between the various groups living in and around the southeastern portion of the Caddo Homeland (Eubanks 2016). Today, Drake's Salt Works contains half a dozen discrete salt flats, all of which are located within about $1.5 \mathrm{~km}$ (1 mile) of each other and are the surface expression of the Drake's Salt Dome. These natural salt deposits are known colloquially as "licks," since they were visited by animals that would lick the brine or salt off the ground surface.
During the protohistoric and early historic periods, the two primary salt-making locales at Drake's Salt Works were the Upper Lick (16WN30) and the Little Lick (16NA11). The Upper Lick is situated on the eastern side of the saline while the Little Lick is located less than a kilometer to the west (Figure 2). Both of these licks contain two separate salt production zones represented by large middens of broken salt bowls, burned earth, and charcoal. At the Upper Lick, the largest of these zones is located on an old terrace remnant in the center of the salt flat, known as "Widdish" Island after the Caddo word for "salt." Recent testing and excavations conducted on this island by The United States Forest Service (USFS) and The University of Alabama revealed that its midden spans an area of almost 1,000 square meters (Eubanks 2016:164). Approximately $80 \mathrm{~m}$ (260 feet) to the west of Widdish 


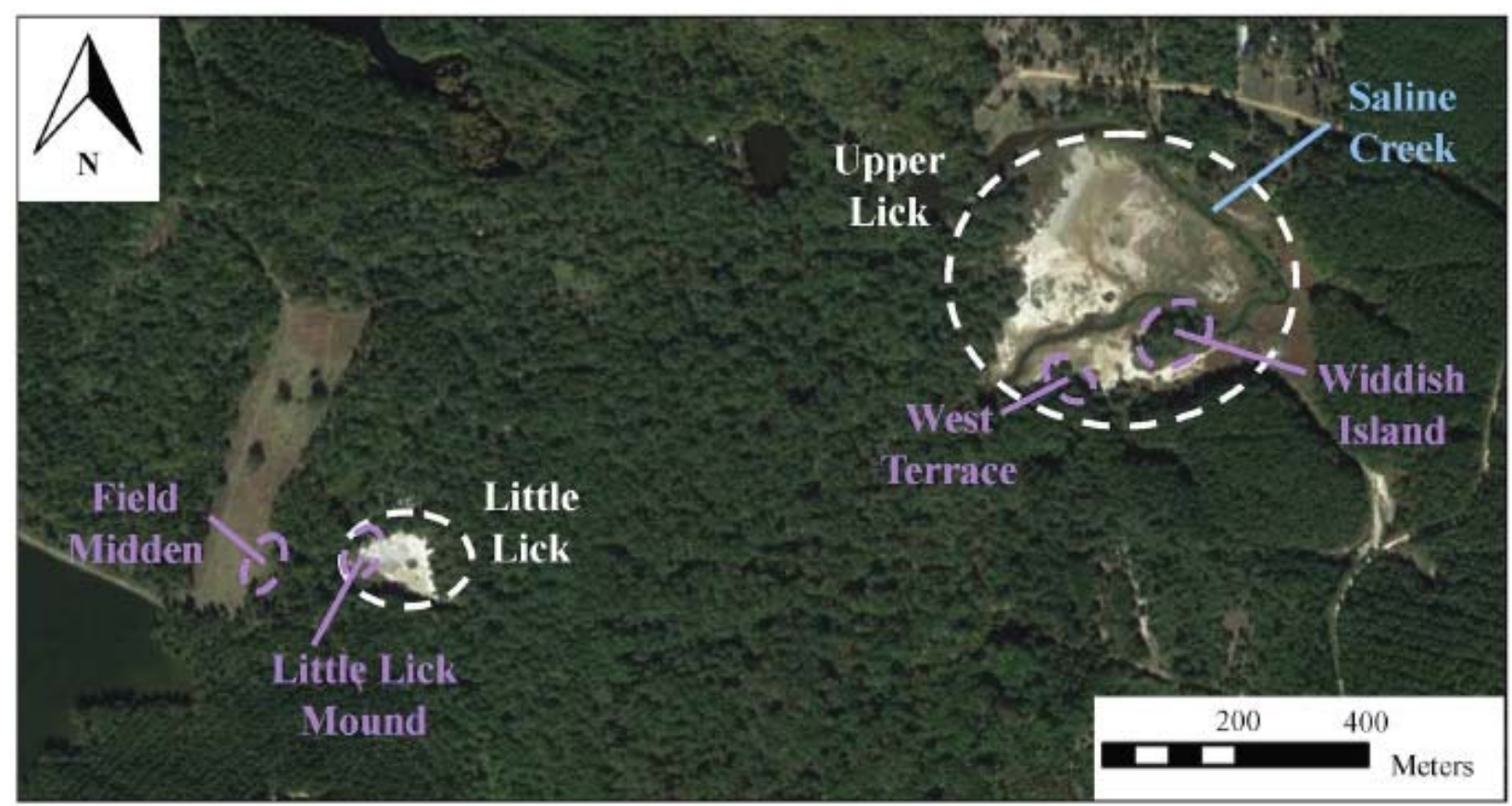

Figure 2. Salt Production Middens (Purple) at the Upper and Little Licks (White). Map data from Google Earth (C) 2012.

Island is a natural terrace with another, slightly smaller midden of salt production debris, referred to here as the "West Terrace."

The two salt production middens at the Little Lick appear to be more or less contemporaneous with their counterparts at the Upper Lick. The largest midden at the Little Lick, known as the "Little Lick Mound," sits on the western edge of the salt flat and is approximately $1 \mathrm{~m}$ high with a diameter of about $25 \mathrm{~m}$. (82 feet) It is composed almost entirely of contact-era salt production debris. Prior to the mound's seemingly rapid construction, the nearest elevated landform to the flood-prone Little Lick would have been in a field roughly $90 \mathrm{~m}$ (300 feet) to the west. The quickest way for a salt producer to reach this field would have been to climb up a fairly steep $6 \mathrm{~m}$-high hill (20 feet). Despite this, there is evidence of a salt production midden in the field at the top of the hill. This locale, referred to here as the "Field Midden," has been heavily disturbed by modern activities and by a Civil War-era salt-making operation (see Figure 2).

The Potter's Pond saline (16WE76) in Webster Parish was also utilized for salt making sometime during the protohistoric to early historic period (Girard 2006:60). This site is located about $70 \mathrm{~km}$ (43 miles) northwest of Drake's Salt Works and was mapped originally by the geologist Arthur C. Veatch (1902) at the turn of the twentieth century. Nearly a century later, in 1983 and 1984, this site was excavated by the Louisiana Archaeological Society (McCrocklin 1985). More recently, in 2005, it was surveyed by Jeffrey Girard at Northwestern State University (Girard 2006:54-69). Since the creation of Lake Bistineau in the early nineteenth century, Potter's Pond has often been at least partially inundated. However, during Girard's survey, the water level had been artificially lowered allowing him to map the site and make note of exposed artifact concentrations. As with the Upper and Little licks, Potter's Pond also contains a slightly elevated, flood-resistant working area with a concentration of salt making debris (Girard 2006:58-59).

During the 2013 excavation season at Drake's Salt Works, AMS radiocarbon samples were taken from the base of the Little Lick Mound and from the base of the Widdish Island midden. The sample from Widdish Island had a 2 Sigma calibrated date range of A.D. 1485 to 1650 while the Little Lick sample yielded a 2 Sigma calibrated date range of A.D. 1470 to 1650 (Table 1). Although European trade based largely out of Natchitoches likely played a major role in shaping the early historic salt trade, this post was not established until 1714. Further, the French likely settled on the 


\begin{tabular}{|l|l|l|l|}
\hline Provenience & Conventional Age & $\begin{array}{c}\text { Measured } \\
\text { Radiocarbon Age }\end{array}$ & 2 Sigma Calibration \\
\hline \hline $\begin{array}{l}\text { Widdish Island } \\
\text { Midden }\end{array}$ & $310+/-30 \mathrm{BP}$ & AD 1620+/-30BP & $\begin{array}{l}\text { Cal AD 1485 to 1650 } \\
\text { (Cal BP 465 to 300) }\end{array}$ \\
\hline \hline Little Lick Mound & $320+/-30 \mathrm{BP}$ & AD 1600+/-30BP & $\begin{array}{l}\text { Cal AD 1470 to 1650 } \\
\text { (Cal BP 480 to 300) }\end{array}$ \\
\hline
\end{tabular}

Table 1. AMS Dates from Drake's Salt Works.

location of Natchitoches, in part, because they wanted to be close to the salt trade, thereby implying that this economic activity was in existence prior to the permanent arrival of Europeans (Castañeda 1936:18; Gregory 1973:255). Thus, while the European demand for salt and salt-treated commodities like meat and animal hides during the eighteenth century was probably a major driving force behind the local and regional salt trades, this demand does not answer the question of why people in northwest Louisiana began making salt in the first place.

\section{The Introduction of the Horse}

One possibility that could have resulted in an increased demand for salt during the protohistoric period is the introduction of the horse, since this animal both craves salt and requires it to live. While wild horses familiar with a particular landscape are capable of acquiring salt on their own, this would likely not be the case for domestic horses or other livestock, especially those recently transported to an unfamiliar geographic region (Alexianu et al. 2015). Thus, domestic horses raised in the Caddo Homeland would likely not know where to go to acquire salt thereby making it necessary for humans to supply them with this substance (Figure 3).

Accounts from early French explorers indicate that by the 1680s some western Caddo groups were raising and trading horses acquired either directly or indirectly from the Spanish in the Southwest (Cox 1905:233; Joutel 1906:148). A few years later in the 1690s, Henri de Tonti noted that horses were common among both the Kadohadacho and the Hasinai (Cox 1905:48-50). Other sources reveal that by the first half of the eighteenth century, the Caddo were trading horses to indigenous groups such as the Quapaw, Tunica, Illinois, as well as to the French (John 1975:199; Swanton 1942:194; Usner 1992:63). While the horse may have been less common among the Caddo when compared to

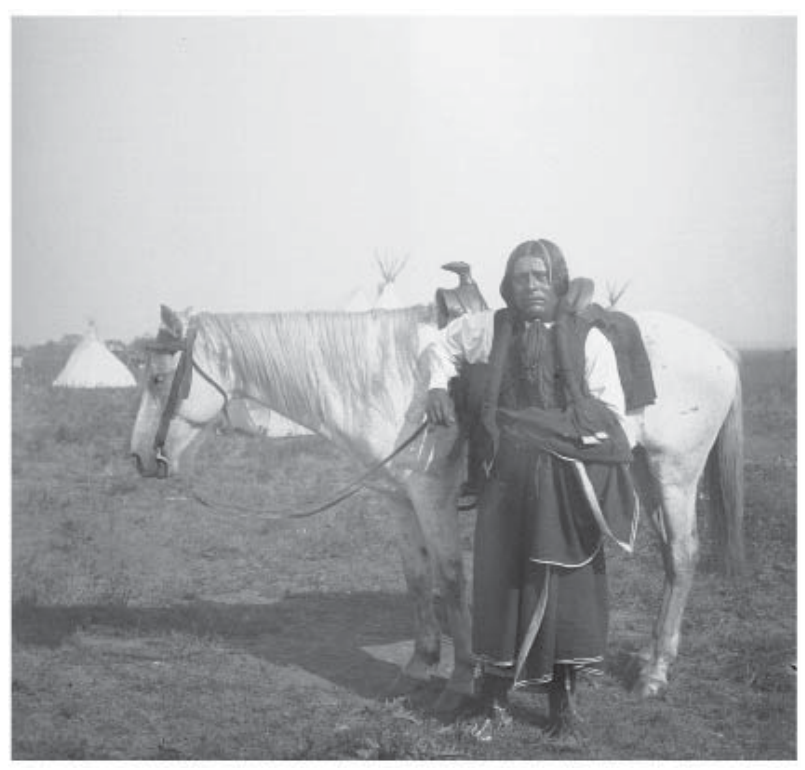

Figure 3. A Caddo Man and his horse, 1893. Reprinted with permission from the National Anthropological Archives, Smithsonian Institution (BAE GN 01373 06259700).

groups from the Plains and Southwest, the wide reaches of the early eighteenth-century Caddo horse trade has led to the argument that the Caddo were "the most experienced horse dealers" in the lower region of French Louisiana (Usner 1992:178). Despite this reputation, the horse may have been a fairly recent addition to the contact-era economies of northwest Louisiana. In the 1720 s, for instance, the French at Natchitoches, having only a few dozen horses and mules, attempted to acquire livestock from the Spanish in east Texas where these animals numbered in the thousands (Burton and Smith 2014:147-148; John 1975:207-208). Within a few years, the French settlers were able to acquire some stock from the Spanish, which they often bred on small islands in the Red River, and by the 1730s, there were hundreds of horses, mules, and cattle in and around Natchitoches (Burton and Smith 2014: 148-149, Table 7.1). While many of these horses belonged to the French, at least some were owned by the local Natchitoches Indians as Winslow Walker (1935:3) reported finding two horse burials during his excavations at the Fish Hatchery site, a cemetery associated with a Natchitoches village.

In the section below, the timing of the diffusion of the horse into the Caddo Homeland is briefly examined. Several approximate dates relating to this diffusion are presented in Figure 4; however, it 


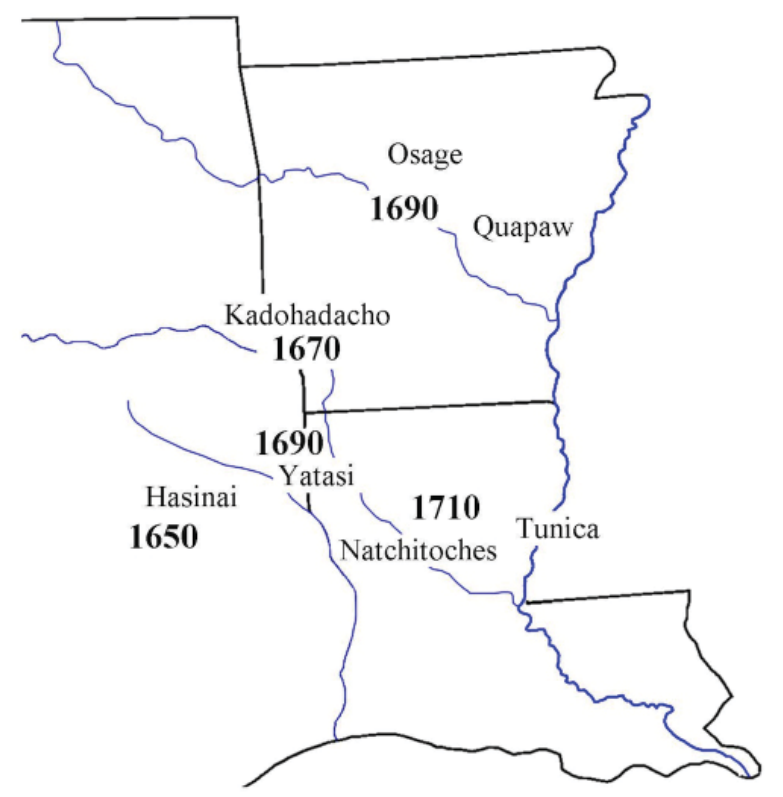

Figure 4. Approximate dates for the diffusion of the horse into the Caddo Homeland.

should be stressed that these dates are speculative and are based on very limited information. While there are several possible avenues through which the Caddo may have procured the horse, it is suggested here that this animal probably arrived into the Caddo region from the west via the southern Plains. Thus, following the suggestion of one reviewer, a distinction has been made below between the Caddo in east Texas who obtained horses at an earlier date and eastern Caddo groups who, presumably, would have acquired horses sometime after their counterparts to the west. In his influential publication "The Influence of the Horse in the Development of Plains Culture," Clark Wissler (1914:2) reasoned that the Caddo "became fully equipped with horses" sometime between A.D. 1600 and 1680. Here, it is suggested that the middle part of this date range may apply to the western Caddo, while the Caddo of northwest Louisiana seem to have acquired the horse about half a century later.

\section{The De Soto Expedition}

Although there were Spanish horses in Florida and along the southern Atlantic coast prior to and shortly after the de Soto expedition in the early 1540s, it is extremely unlikely that these horses were captured, bred, and traded westward to the Caddo (Chard 1940:91-92; Clayton et al. 1993:II:251). Instead, many horses from early Spanish explorations were either killed by Indians or eaten by the starving conquistadors (Hudson 1997). Horses that managed to escape these fates often became sick and died, perhaps in part, due to the same lack of salt experienced by the Spanish soldiers (Clayton et al. 1993:I:383-384). Excluding the very unlikely possibility of a rapid westward diffusion from Florida, the first time Caddos would have seen horses would have been during the early 1540s on the de Soto expedition. However, there is no written evidence that horses were traded to or captured by any indigenous populations at any time during the expedition.

Francis Haines (1938) speculates that one or more indigenous groups conceivably could have gotten horses from the de Soto expedition in the vicinity of east Texas. Nevertheless as Thornton Chard (1940:92) points out, by the time de Soto reached the west bank of the Mississippi, more than half of his original 200 horses had already been killed. In the spring of 1542 , only 22 of de Soto's original 200 horses remained to be ferried down the Mississippi River, and of this number, only a handful escaped the mouths of the hungry Spanish (Chard 1940:99-100). This, along with the propensity for many indigenous groups to kill de Soto's horses and the fact that mares were rarely taken on long expeditions, makes it doubtful that a breeding population of domestic horses was established by any group in the Southeast as a result of the de Soto entrada (Chard 1940).

While the Caddo probably did not receive horses from the de Soto expedition, this does not mean that they would not have seen how the Spanish treated and cared for their animals. For instance, there were times that de Soto's soldiers were known to have acquired salt from various groups in the Southeast, including the Caddo (Clayton et al. 1993:I:124-125, 142). As the men on the de Soto expedition were in dire need of salt, it is reasonable to infer that their horses also experienced a similar need. Thus, when the Spanish were able to obtain salt, it is likely that they reserved at least a portion of their supply for their horses. If this act did not go unnoticed, then perhaps the Caddo and other groups in the Southeast recognized that horses, like humans, crave salt. 


\section{The Southwest and Southern Plains}

It is generally believed that the horse diffused into the Caddo Homeland via the Southwest (e.g., Fletcher 1907; John 1975; Swanton 1942:36-37, 193; Usner 1992:177; Wisler 1914:2). The first time that many people in the Southwest would have seen a horse came in the early 1540s during the Francisco Vasquez de Coronado expedition. Following a brief foray into New Mexico by Fray Macros de Niza and Estéban, a survivor of the de Vaca expedition, Coronado led several hundred soldiers, numerous Mexican Indian allies, several priests, and as many as 1000 horses and hundreds of other livestock into the Southwest. While a few of these horses are known to have escaped, it is unlikely, especially given the lack of mares, that enough were lost to sustain a herd or for a breeding population to be established (Morris 2003:229; De Steiguer 2011:69-70).

The next major Spanish move into the Southwest occurred several decades later with a sustained effort at settlement and missionization. In 1598, after several years of attempting to organize an expedition into New Mexico, Don Juan de Oñate, ventured into the Southwest and the southern Plains. With him were 400 men, many of whom brought their families; almost 100 wagons and carts loaded with supplies; and thousands of horses and other livestock (De Villagrá 2004:xxvii). From this time on and especially after the establishment of Santa Fe in 1610, Pueblo groups would have had access to Spanish horses. However, these animals would have been a prime target for raiding parties. For instance, by the first decade of the seventeenth century, various Apache groups were known to have routinely relieved the Spanish and Pueblo of some of their horses (John 1975:55-57). The horse, in turn, dramatically increased the Apache's range for trading, raiding, and hunting. As a result, by the midseventeenth century, the Apache were also encroaching into the western Caddo Homeland.

Other groups from the southern Plains with horses, such as the Jumano, were also in contact with western Caddo groups in east Texas as early as the 1630s and 1640s (John 1975:166-171). Thus, it would not be surprising if the horse was present in east Texas shortly thereafter, perhaps sometime around 1650. For the next several decades, the Jumano served as middlemen in a trading network stretching from the Southwest across the southern Plains to the western Caddo Homeland. Similar to the Spanish and Pueblo, the Jumano were also harassed by the Apache. This harassment intensified after the Pueblo Revolt of 1680 with the Jumano pleas for help from the Spanish at El Paso going unanswered. Without support from the Spanish, the Jumano were no longer able to continue their role as middlemen in the horse trade (John 1975:171-180). While this may have served to limit interaction between the Caddo of east Texas and groups to the west after 1680, it is almost certain that at least some western Caddo villages had acquired the horse by this point. Only six years later, for instance, the horse was common enough among some Hasinai that Henri Joutel, a member of the La Salle expedition, reported that he was able to trade only one axe for a horse (Joutel 1906:148). Another member of this expedition, Father Anastasius, claimed to have been offered a horse in exchange for a cowl (Cox 1905:233). In 1690, a Hasinai group gave Henri de Tonti four horses, two of which had been branded by the Spanish. In addition, de Tonti noted that horses were also common among the Kadohadacho to the northeast with one of their villages containing approximately 30 horses (Cox 1905:48-50).

By 1711, Caddos in the vicinity of southwestern Arkansas were trading Spanish horses to Indian groups in Illinois in exchange for French trade goods (John 1975:199). Similarly, by the early 1720s, if not slightly earlier, French traders were being supplied with horses from groups to the north and east of the Caddo, including the Osage and the Tunica (Surrey 1916:301; Usner 1992:63). While the Tunica may have acquired some of their horses via trade networks to the west, the preferred method among the Osage for obtaining horses seems to have been raiding, especially after the Pueblo Revolt (Rollings 1995:101-102).

Around this time, the Quapaw in eastern Arkansas also seem to have acquired the horse. When Joutel visited this group in 1687, he did not mention them owning any horses. However, when they departed the village, Joutel's party left their horses behind, meaning that the Quapaw would have had access to horses by at least 1687 (Arnold 2000:19; Lewis 1924:256). 
The Terán Expedition

Another potential source of horses and other livestock for the Caddo would have been the 1691-1692 Terán expedition. The purpose of this expedition was to establish missions among the Tejas Indians and to remove individuals who had illegally settled on lands claimed by Spain. However, the expedition was not successful and largely served to worsen relations between the Spanish and Tejas (Weber 1992:115). Terán reported that the Hasinai stole their horses and mules, which is not surprising given that he refused to pen these animals to prevent them from trampling the Caddos' crops (Chipman and Joseph 2010:94; John 1975:191). Not including theft, the stampeding alone may have resulted in the loss of more than 100 horses (Jordon 2004:98-99). While these animals could have served as a source of stock for groups like the Hasinai, the horse is known to have been in this region by the 1680 s, and could have been present several decades before this (Cox 1922:233; Joutel 1906:148).

As Terán neared the Red River, he may have passed near lands affiliated with the Yatasi. Given the propensity for Terán's livestock to go missing, it could be the case that the Yatasi were able to acquire stock from the Terán expedition. If so, then it is also possible that a number of these animals came with some of the Yatasi in the 1710s when they moved to the southeast to settle near the Natchitoches following a series of attacks by the Chickasaw (John 1975:204-205; Swanton 1942:7, 57). Given the French reports of there being several dozen horses and livestock in Natchitoches by 1722, it would not be too much of a stretch to say that these animals were present in northwest Louisiana by at least the 1710s and that some of these may have belonged to the Yatasi or were descended from stock on the Terán expedition (Burton and Smith 2014:147-148).

\section{Horses, Salt, and Sustained European Contact}

Although the precise date for their appearance throughout the Caddo Homeland is up for debate, once they were there, horses, like other types of livestock, would have needed salt. Thus, the presence of horses in the western and central parts of the Caddo Homeland would have created a need for this substance. Much of this need could have been fulfilled by salines in east Texas. However, it is possible that a portion of the demand for salt was met by Caddos to the east at places like Drake's Salt Works and Potter's Pond. If so, then the introduction of the horse might be one reason to help account for the onset of protohistoric salt production in northwest Louisiana.

Regardless of what may have initially motivated the inhabitants of northwest Louisiana to start making salt, once the French and Spanish arrived on a permanent basis, the demand for salt would have increased substantially (Eubanks 2016). While there is little to no evidence to suggest that salt was used to preserve meat in prehistoric times, this was not the case following European contact since several indigenous groups were known to have been involved in the trade of salted meats (Gregory 1973:253-269; Hawkins 2003:21; Hubert 1717). Horses and other livestock in and around Natchitoches would also need to be supplied with salt, especially after the $1730 \mathrm{~s}$, when these animals became fairly abundant (Burton and Smith 2014:147-148). In addition, the high demand for deerskins and other animal hides on the French market meant there was a considerable demand for salt since Europeans often used this mineral in the hide tanning process. Thus, by the early-mid eighteenth century, it would have been the European demand for salt and salt-treated commodities at places like Natchitoches that would have been driving the local salt trade.

\section{Raiding}

Given the value of salt in contact-era northwest Louisiana, it would not be surprising if the transfer of this commodity from one group to another was not always a friendly affair. Although numerous environmental and economic considerations likely impacted the salt trade, territorial encroachment and theft may have also affected when and where salt was produced and traded. The potential for these factors to impact the salt trade would have been especially apparent after the introduction of the horse, since this animal increased the range and effectiveness of raiding parties. The American Indian Agent John Sibley provides some insight into the problem of raiding at Caddo salines when he reported in 1807 : 
Three Caddos arriv'd special messengers from the Caddo chief to inform me that a party of Chactas consisting of eight persons from the great nation under a leader called Stamelachee had lately been at a camp of Nandacos at a saline on the River Sabine where the Nandacos live, the men being out hunting and left their women to make salt and had murdered two of the women and wounded some others [emphasis added], without any provocation and brought the scalps of the women through the Conchetta village on their way to the great Chacta Nation (Sibley 1922:22-23; see also Swanton 1942:82).

If protecting their salt from hostile groups was a concern for the salt producers of northwest Louisiana, then perhaps one of the ways that these individuals could have dealt with this problem would be to only make salt at places where they had a commanding view of their surroundings so that they could easily spot approaching raiding parties. If this was the case, then utilized salines in northwest Louisiana might be expected to have larger areas of visibility, or "viewsheds," when compared to salines that were not utilized. In addition, salt producers may have preferred to work at salt licks located in close proximity to each other in an effort to find strength in numbers. In order to test these two ideas, spatial analyses involving fourteen recently surveyed salt licks in northwest Louisiana were conducted using Arc GIS. The majority of these surveys were conducted between 2011 and 2014 by the University of Alabama and the USFS. Potter's Pond was surveyed in 2005 by Jeffrey Girard (Eubanks 2014; Girard 2006:5469). Of the fourteen surveyed licks, only three yielded definitive evidence of sustained usage in the form of large quantities of ceramic salt-making debris (Eubanks 2016:177; Girard 2006:54-69) (Figure 5). While this work did not encompass all of northwest Louisiana's known salt deposits, these data can nevertheless provide some meaningful insight into salt lick preference during the contact era.

\section{Visibility}

Following the reasoning that if salt producers were concerned about raiding they would prefer to have large

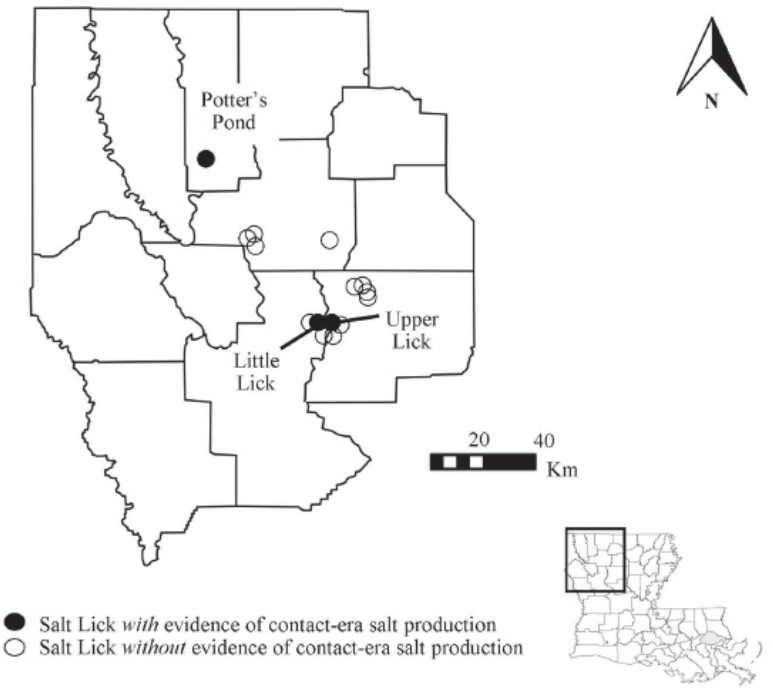

Figure 5. Salt Licks with evidence of contact-era salt production (modified from Eubanks 2014:Figure 9).

viewsheds, visibility analyses of the aforementioned salt licks were conducted using $5 \mathrm{~m}$ (16 feet) resolution LiDAR digital elevation data available online at https:// atlas.ga.lsu.edu/. At salt licks with evidence of usage in the form of production middens, viewshed analyses were conducted from the highest elevation at each production zone, or "viewshed observation point," using a standard observer height of $1.7 \mathrm{~m}$ (5.5 feet). For salt licks without middens of production debris, the highest elevation point within $100 \mathrm{~m}$ (325 feet) of the salt flat was used as the point of observation. This somewhat arbitrary distance was employed following the logic that prospective salt producers would likely not want to transport large quantities of brine, fuel, and salt-enriched soil more than a short distance from the salt lick.

At the Little Lick at Drake's Salt Works, there were two viewshed observation points corresponding to the two middens of salt production debris. These points are located on top of the Little Lick Mound and in the adjacent field roughly $90 \mathrm{~m}$ (300 feet) to the west of the salt flat (see Figure 2). From the highest point on the Little Lick Mound, an observer can easily see the entirety of the salt flat (Figure 6). Such a view may not have been present from the field during early historic times, since, unlike the salt flat, the hill separating this locale from the Little Lick can support the growth of large trees and other types of sight-blocking vegetation. However, if the salt producers needed more wood for 


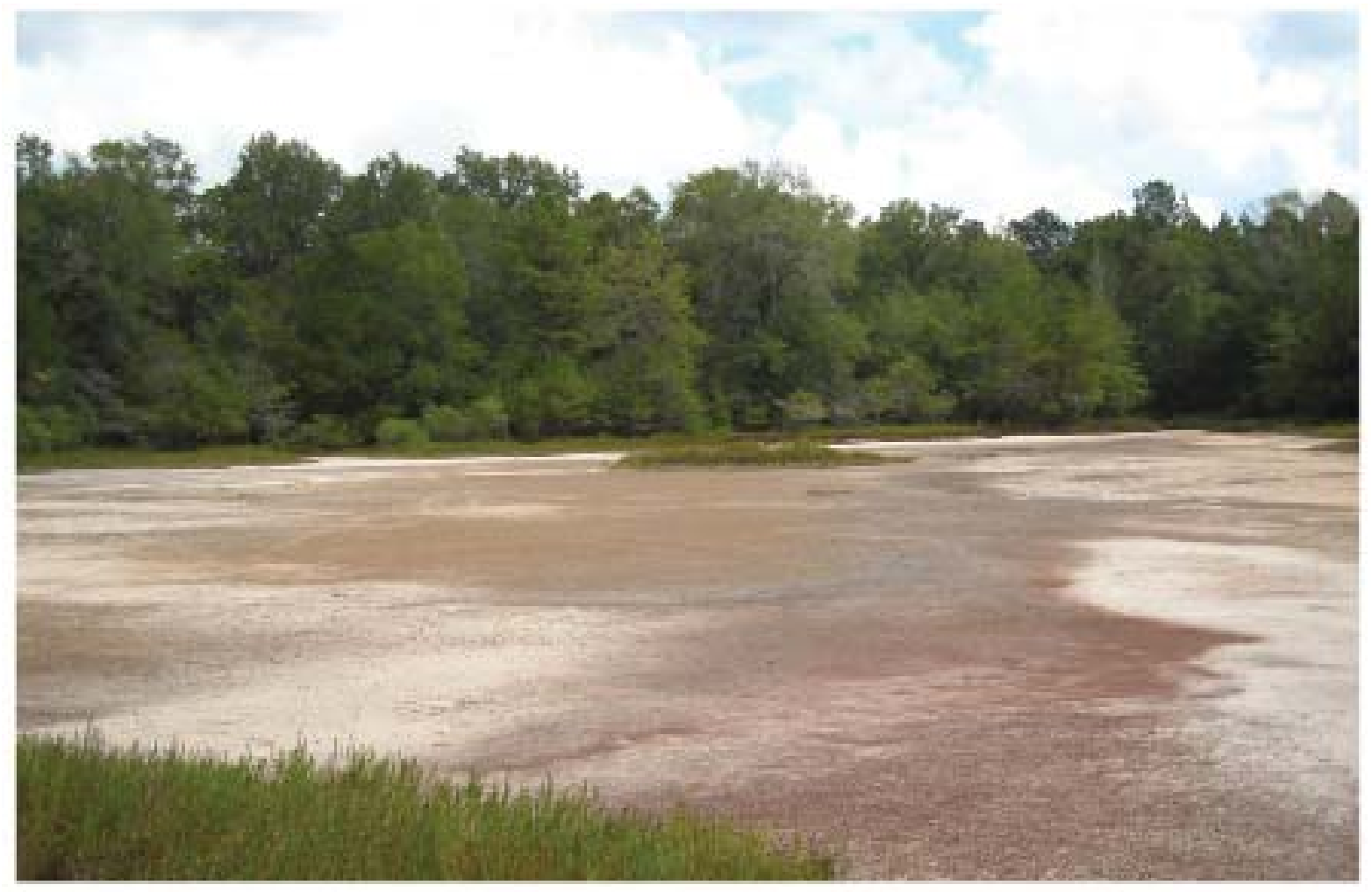

Figure 6. Photograph of the Little Salt Flat as seen from the Little Lick Mound.

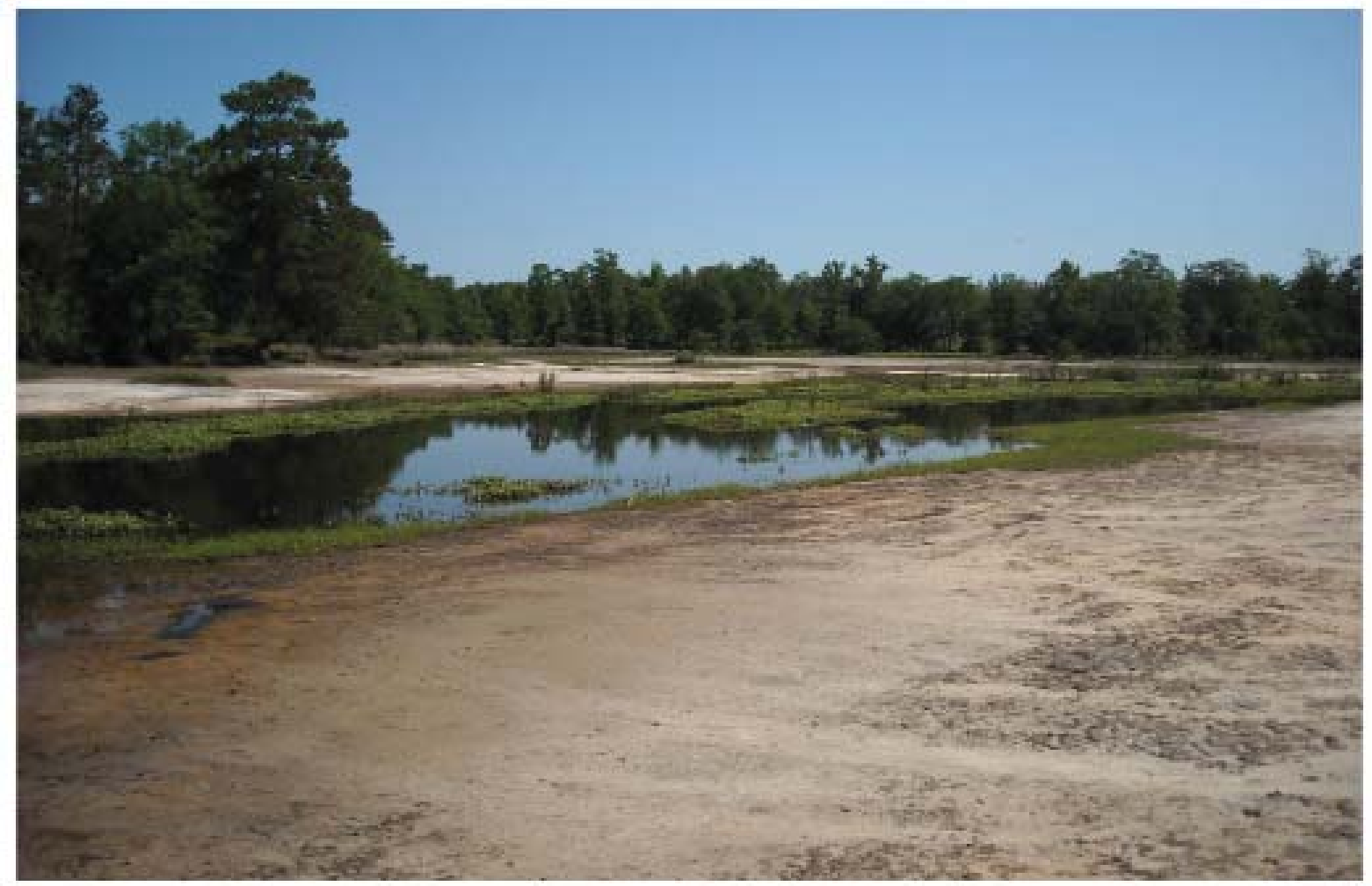

Figure 7. Photograph of the Saline Creek and the Upper Salt Lick Flat as seen from the west terrace. 


\section{Site}

$\frac{\text { Utilized Licks }}{\text { Potter's Pond }}$

Little Lick Field

Little Lick Mound

West Terrace, Upper Lick

Widdish Island, Upper Lick

\section{Mean Viewshed}

Viewshed (ha)

1216

178

19

23

27

293 (62 without Potter's Pond)

Table 2. Viewsheds for Utilized Salt Licks.

fuel than what could be provided by simply collecting limb fall, then they may have concentrated their clearing efforts on the forested hill between the two production locales. In doing so, it is possible that these individuals may have had a partial view of the salt flat.

Like the Little Lick, the Upper Lick at Drake's Salt Works also contains two salt-working areas. While relatively flat, the highest elevation point at each of these middens was used to conduct the viewshed analysis. One of these viewshed observation points is located on Widdish Island while the other is on the West Terrace (see Figure 2). Widdish Island is surrounded by saltenriched soils and is thus generally devoid of vegetation, making it fairly easy to see anyone approaching the island via land. In addition, Saline Creek, which runs through the center of the Upper Lick is also visible from Widdish Island. Similarly, producers working on the West Terrace would have had a clear view of Saline Creek and the Upper Lick salt flat, though they would have been bordered to the south and west by trees, which would have reduced their total visibility (Figure 7).

At Potter's Pond, the landscape is generally flat, but it would still be challenging for the salt makers to spot approaching raiding parties or to keep an eye on the nearest waterway due to the surrounding vegetation. As one reviewer pointed out, even when the lake is drawn down and vegetation is relatively minimal, it is still difficult to see over long distances when standing at the lick. Although the people making salt at Potter's Pond may not have been able to see the nearest waterway or sight over long distances, they would have been only a couple hundred meters from Bayou Dorcheat, a tributary of the Red River.

\section{Site}

Unutilized Licks

Drake's Big Lick

Durbin Lick

Jack's Lick

King's Big Lick

King's Upper Lick

Lower Lick

Open Lick

Price's Big Lick

Price's Lick

Smith's Lick

Tilly Lick

Mean Viewshed
Viewshed (ha)

192

9

149

36

29

508

201

151

53

161

192

153

Table 3. Viewsheds for Unutilized Salt Licks.

The results of the viewshed analyses for the surveyed salt licks in northwest Louisiana are presented in Tables 2 and 3. The mean viewshed area for utilized salt licks is 293 ha (720 acres) while the mean area for unutilized licks is 153 ha (378 acres). The former figure is skewed upward by Potter's Pond, which has a viewshed of over 1200 ha (2965 acres). This figure is probably being inflated to some extent by the flat surface of Lake Bistineau, which was created at the turn of the nineteenth century. When Potter's Pond is removed from the analysis, the mean area of visibility for utilized salt licks drops to 62 ha (153 acres), which is less than half of the mean viewshed area for unutilized licks. Even if the figure for Potter's Pond is included, the difference between these viewsheds is still not statistically significant with a Mann-Whitney U Test p-value of .25. Thus, it would seem that simply having a large area of visibility would not have been the sole deciding factor for salt producers when selecting which salt licks they wanted to use. It is important to keep in mind, however, that oftentimes what could be seen is just as important, if not more important, than how much could be seen.

It is probably no coincidence that all of the known salt production locales in northwest Louisiana are located within a couple hundred meters of a creek or bayou that feeds into the Red River. These waterways, along with facilitating transportation and trade, could have been monitored by the salt producers either directly from the lick or indirectly with the aid of a spotter. Thus, 
if a hostile group was spotted approaching on foot or on horseback, then the producers could escape into the creek or bayou using their canoes. Further, the creeks and bayous could have also served as natural barriers. For instance, if a raiding party was approaching the salt lick from the opposite side of the creek, then they would first have to cross the creek to reach the salt producers, thus giving the latter more time to notice and react to the presence of the former.

In addition to working near waterways, there may have been other steps that the salt producers could have taken to help protect themselves from raiding. At the Upper Lick, the two production zones are separated by less than $100 \mathrm{~m}$ (328 feet) and are not only mutuallyvisible, they are also easily within shouting distance. As a result, if only one producer spotted a raiding party, that individual could warn all of the salt makers working at the lick. A similar tactic could have been employed at the Little Lick since the two production zones are also located within less than $100 \mathrm{~m}$ (328 feet) of each other. Further, if the Upper Lick and the Little Lick were used at the same time, which the available AMS and ceramic data indicate is a possibility, then perhaps the various salt making groups at the Upper and Little licks were attempting to protect themselves from raiding by having a large number of producers that could defend the two salt-making operations.

While it is doubtful that groups working at the Upper and Little licks would have been able to hear each other directly, they may have been in indirect communication. For instance, if there were one or two people stationed between these licks then warnings or other types of information could be exchanged fairly quickly. In addition, if a producer from one lick ran a few hundred meters toward the other, then this individual probably could have been heard by the producers at the other lick. Thus, if the people at one salt lick were attacked, then they could seek help from their counterparts at the other salt lick, or at the very least, warn them of the potential for danger.

\section{Traveling Salt Makers and the Distribution of Utilized Salines}

Although the scenarios described above are somewhat speculative, the idea that raiding was a concern for contact-era salt producers would help account for the regional distribution of salt production sites in northwest Louisiana. If groups of salt producers chose to work in close proximity to each other to guard against raiding, then some of these groups may have needed to travel fairly long distances in order to reach safe salt-making localities. This may explain why the Upper and Little licks were utilized by multiple salt-making populations when there would have been many other unutilized licks elsewhere in northwest Louisiana (Eubanks 2014).

The potentially-simultaneous use of the Upper and Little licks would also make sense if these salt makers were part of the same or closely-related cultural groups. In this sense, raiding may not have been an issue; instead they may have simply lived near the Upper and Little licks and elected to use these two salt resources for the sake of convenience. However, this does not seem to have been the case since the decorated pottery at the Upper Lick resembles other local late prehistoric/early historic Caddo assemblages while the decorated sherds from the Little Lick appear to be more at home in the Lower Mississippi Valley (Figures 8 and 9). The presence of these apparent non-local sherds suggests that the Little Lick was used by a group of salt makers who may have traveled hundreds of kilometers in order to reach the Little Lick. If this is correct, then this phenomenon would not be too out of the ordinary since groups from the vicinity of west Mississippi were traveling to south Louisiana to make salt at Salt Mine Valley during the protohistoric period (Brown 1999:122). In addition, Antoine-Simon Le Page du Pratz provided evidence for the existence of traveling salt producers in Louisiana when he reported, "The natives come from quite long distances to this place to hunt here during the winter and to make salt here" (Swanton 1911:78).

Given the Little Lick's location within a geographic area typically associated with the protohistoric and early historic Caddo, one may speculate that the Upper and Little lick salt makers, despite their cultural differences, were on at least somewhat friendly terms and that the former may have even "allowed" the latter to work at the Little Lick. The Taensa, for instance, seem to have known of the location of Caddo salt deposits in northwest Louisiana, and it could be the case that the use of this or another 

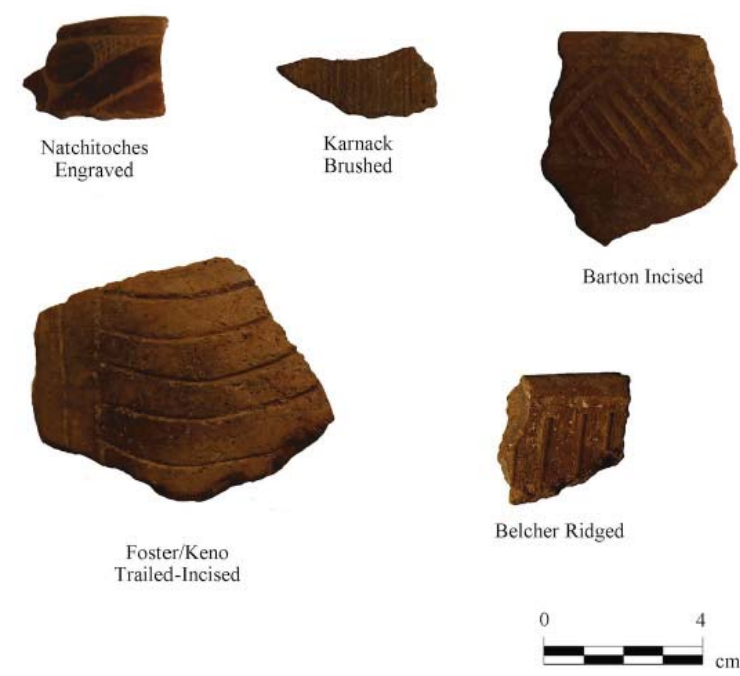

Figure 8. A sample of decorated sherds from Upper Lick.

nearby saline was a part of their 1690 treaty with the Natchitoches mediated by Henri de Tonti (John 1975:186). While speculative, it is also possible that the people working at the Little Lick had once been able to acquire enough salt through production or trade closer to home but were cut off from their supply sometime during or shortly after the protohistoric period. In such a scenario, groups like the Taensa or Tunica, who were known historically to have been active in the salt trade, may have decided to start making salt themselves rather than acquiring it via trade. If this was the case, then the journey to the Little Lick would not have been insurmountably difficult since this trip could be completed almost entirely by canoe given that the Mississippi River connects with the Red River, which in turn connects to the Upper and Little licks (see Figure 1). Working closer to the French at Natchitoches may have also helped to curb the threat of raiding as the salt producers and traders would have been relatively close to the military outpost at Fort St. Jean Baptiste. In addition, they would have less distance to travel to the Natchitoches trading post, and thus, fewer opportunities to be attacked.

\section{Environmental Considerations}

Aside from the potential for raiding, another concern for the salt producers of northwest Louisiana would have been prolonged rainfall, since most of the low-lying salt flats in this part of the state are prone to flooding. At the
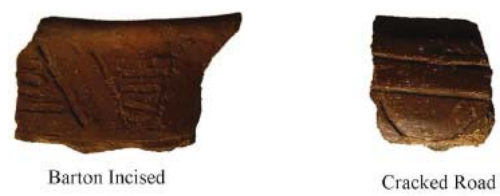

Incised

Maddox Engraved
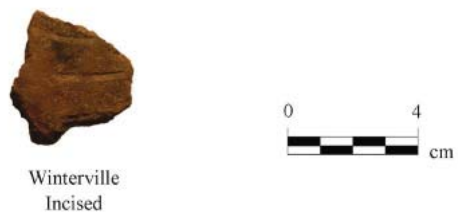

Owens Punctated

Incised

Figure 9. A sample of decorated sherds from Lower Lick.

Upper Lick, flood-resistant landforms occur naturally on the landscape in the form of Widdish Island and the terrace surrounding portions of the salt flat. These elevated landforms would have been beneficial as they provided dry land on which the producers could work when the salt flats were flooded or when they were too soggy to boil brine. Given the advantages of such a landscape, it would be surprising if salt producers chose to work at a saline where there was not some type of elevated landform or one immediately adjacent to the salt flat. Nevertheless, this is exactly what is seen at the Little Lick. The only naturally-elevated landform at this site is at the top of the $6 \mathrm{~m}$-high hill $90 \mathrm{~m}$ (300 feet) to the west of the salt lick. Carrying fuel, brine, and salt-enriched soil up and down this hill, while certainly not impossible, would have been difficult, especially if children and the elderly were involved in this process (Eubanks 2015). If working near the Caddo at the Upper Lick was a priority for the traveling salt producers, then this would help account for why they chose to work at the Little Lick when there were other licks with landscapes seemingly more conducive to making salt elsewhere in Louisiana. The use of a flood-prone salt flat like the Little Lick might also be explained if the producers were simply not concerned with having elevated working platforms. However, this was almost certainly not the case, since the Little Lick salt producers constructed a flood-resistant platform, in the form of the Little Lick Mound, along the edge of the salt flat. Thus, the construction of this mound meant that the people at the Little Lick could be near the producers at the Upper Lick without having to climb up and down a hill in order to make salt on dry land. 


\section{Conclusions}

At present, there is little evidence to suggest that largescale salt production occurred in northwest Louisiana prior to A.D. 1600. Compared to other parts of the Caddo Homeland, the beginning of the salt industry in this region appears to have been delayed by at least two centuries if not slightly longer (Early 1993; Eubanks and Brown 2015; Kenmotsu 2005). Additionally, it does not seem prudent at this point to suggest that dietary motivation alone was the primary reason the occupants of northwest Louisiana began making salt.

The first part of this article introduces the possibility that some of the early demand for salt in northwestern Louisiana was partially a result of the spread of the horse into the Caddo Homeland. While horses both crave and need salt, the potential impact of this animal and other livestock on the early salt trade in Louisiana is still far from clear. However, by the 1730s, only two decades after the establishment of Natchitoches, there would have been hundreds of salt-hungry horses, cattle, and mules in northwest Louisiana (Burton and Smith 2014:147-148). Thus, it is not unreasonable to think that a portion of the salt made in this region could have been given to these animals. Although some salt may have been reserved for animals, the European demand for salt and salt-treated commodities like meat and animal hides during the eighteenth century may have been the most important driving force behind the local salt trade (Eubanks 2014). In the second part of this article, it is suggested that raiding may have also had an impact on northwestern Louisiana's salt industry. Based on limited historic evidence, it is known that at least some raiding was occurring at Caddo salines in east Texas (Sibley 1922:22-23; Swanton 1942:82). If this threat was present in northwest Louisiana, then it is possible that the salt producers could have dealt with this problem by using salt licks bordered by waterways, by working in close proximity to other producers, and by traveling long distances to reach well-protected salines. Raiding may have also been an issue for the individuals involved in trading the salt once it was produced. However, in the case of Drake's Salt Works, this threat was mitigated to some extent since this site complex is only about $30 \mathrm{~km}$ (18 miles) from Natchitoches on land or about $60 \mathrm{~km}$ (37 miles) if only waterways are used.
It is still unclear to what extent raiding from hostile groups, such as the Osage and Choctaw, would have concerned the salt producers of northwest Louisiana. However, what is clear is that there would have been many other unutilized salt licks in this region aside from those at Drake's Salt Works that the non-local producers at the Little Lick could have utilized but did not. If the threat of raiding encouraged groups from the Lower Mississippi Valley to travel to the Little Lick in an effort to find strength in numbers with the Caddo at the Upper Lick, then this would help account for the spatial distribution of salt making sites in northwest Louisiana. While factors such as brine purity and strength may have influenced the distribution of salt production to some extent, it is worth pointing out that there are other salt licks in this region with stronger and purer brine than the Upper and Little licks (Veatch 1902:94-95). Thus, it would seem that other non-environmental considerations, such as raiding, might have also been on the minds of the contact-era salt producers in northwest Louisiana.

\section{Notes}

1. Here, a distinction is made between producing salt and gathering salt. The former technique is much larger in scale and often generates considerable quantities of debris resulting from the artificial heating of brine (e.g., broken saltpan sherds, burned earth, fire-cracked rock, and charcoal). On the other hand, activities like gathering a few scoops of salt from a dry lick or filling up a handful of containers with brine are much smaller in scale and may leave behind few, if any, archaeological remains.

\section{Acknowledgements}

Financial support for this research was provided by the National Science Foundation, the Avery Island Inc./ McIlhenny Company, and The University of Alabama. In addition, I would like to thank Ian Brown, Ashley Dumas, Ann Early, Steve Kosiba, Velicia Bergstrom, and Daniel Cain for their assistance with interpreting and collecting the data presented in this paper. However, as always, any incorrect or overzealous interpretations are the responsibility of the author. Lastly, this paper benefited greatly from the comments provided by two anonymous reviewers. 


\section{References Cited}

Alexianu, Marius, Felix Adrian Tencariu, Andrei

Asândulesei, Olivier Weller, Robin Brigand, Ion Sandu, Gheorghe Romanescu, Roxana-Gabriela Curcâ, Ştefan

Caliniuc, and Mihaela Asândulesei

2015 The Salt from Alghianu Beck (Vrancea County, Romania): A Multifaceted Ethnoarchaeological Approach. In The Archaeology of Salt: Approaching an Invisible Past, edited by Robin Brigand and Olivier Weller, pp. 47-63. Sidestone Press, Leiden.

Arnold, Morris

2000 The Rumble of a Distant Drum: The Quapaws and Old World Newcomers, 1673-1804. University of Arkansas Press, Fayetteville.

Brown, Ian W.

1980 Salt and the Eastern North American Indian: An Archaeological Study. Lower Mississippi Valley Survey Bulletin No. 6. Peabody Museum, Harvard University, Cambridge.

1999 Salt Manufacture and Trade from the Perspective of Avery Island, Louisiana. Midcontinental Journal of Archaeology 24(2):113-151.

2004 Why Study Salt? Journal of Alabama Archaeology 50(1):36-49.

Burton, H. Sophie and F. Todd Smith

2014 Colonial Natchitoches: A Creole Community on the Louisiana-Texas Frontier. Texas A\&M University Press, College Station.

Castañeda, Carlos E.

1936 Catholic Heritage in Texas, 1519-1936, Vol. 1, The Mission Era: The Finding of Texas, 1519-1693. Von Boeckmann-Jones Company, Austin.

Chard, Thornton

1940 Did the First Spanish Horses Landed in Florida and Carolina Leave Progeny? American Anthropologist 42(1):90-106.
Chipman, Donald E. and Harriett Denise Joseph

2010 Spanish Texas:1519-1821, Revised edition.

University of Texas Press, Austin.

Clayton, Lawrence A., Vernon J. Knight, and Edward C.

Moore (editors)

1993 The DeSoto Chronicles: The Expedition of Hernando de Soto to North America in 15391543. 2 Vols. The University of Alabama Press, Tuscaloosa.

Cox, Isaac J.

1905 The Journeys of Rene Robert Cavelier, Sieur de La Salle, Vol. 1. Allerton Book Co., New York.

De Steiguer, J. Edward

2011 Wild Horses of the West: History and Politics of America's Mustangs. The University of Arizona Press, Tucson.

De Villagrá, Gaspar Pérez

2004 Historia de la Nueva Mexico, 1610: A Critical and Annotated Spanish/English Edition. Translated by Miguel Encinias and Alfred Rodriguez. University of New Mexico Press, Albuquerque.

Dumas, Ashley A.

2007 The Role of Salt in the Late Woodland to Early Mississippian Transition in Southwest Alabama. Ph.D. Dissertation, Department of Anthropology, The University of Alabama, Tuscaloosa.

Early, Ann M.

1993 Hardman and Caddoan Saltmaking. In Caddoan Saltmakers in the Ouachita Valley: The Hardman Site, edited by Ann M. Early, pp. 223-234. Research Series No. 43, Arkansas Archeological Survey, Fayetteville.

Eubanks, Paul N.

2014 The Timing and Distribution of Caddo Salt Production in Northwestern Louisiana. Southeastern Archaeology 33:108-122.

2015 A Reconstruction of the Caddo Salt Making Process at Drake's Salt Works. Caddo Archeology 25:145-166. 
2016 Salt Production in the Southeastern Caddo Homeland. Ph.D. Dissertation, Department of Anthropology, The University of Alabama, Tuscaloosa.

Eubanks, Paul N. and Ian W. Brown

2015 Certain Trends in Eastern Woodlands Salt Production Technology. Midcontinental Journal of Archaeology 40(3):231-256.

Fletcher, Alice C.

1907 Caddo. Bulletin of the Bureau of American Ethnology 30:179-182. Reprinted with permission of the Smithsonian Institution, Washington, D.C.

Girard, Jeffrey S.

2006 Sites at Lake Bistineau. Regional Archaeology Program Management Unit 1, Seventeenth Annual Report, Northwestern State University. Report prepared for Northwestern State University, Natchitoches, Louisiana and the Louisiana Division of Archaeology, Department of Culture, Recreation, and Tourism, Baton Rouge.

Gregory, Hiram F.

1973 Eighteenth Century Caddoan Archaeology: A Study in Models and Interpretation. Ph.D. Dissertation, Department of Anthropology, Southern Methodist University, Dallas.

Haines, Francis

1938 Where Did the Plains Indians Get Their Horses? American Anthropologist 40(1):112-117.

Hawkins, Benjamin

2003 The Collected Works of Benjamin Hawkins, 1796-1810. Edited and with an Introduction by H. Thomas Foster, II, The University of Alabama Press, Tuscaloosa.

Hubert, Julien

1717 Réponses du Sieur Hubert aux Observations du Sieur Cadot. Imp. de Gissey, Paris.
Hudson, Charles M.

1997 Knights of Spain: Warriors of the Sun. University of Georgia Press, Athens.

John, Elizabeth A.H.

1975 Storms Brewed in Other Men's Worlds: The Confrontation of Indians, Spanish, and French in the Southwest, 1540-1795. Texas A\&M University Press, College Station.

Jordan, Sheila Pat

2004 The Terán de los Ríos-Massanet Expedition of 1691: A Scholarly Edition and Comparative Study. M.A. Thesis, Department of Modern Languages, Texas A\&M University, College Station.

Joutel, Henri

1906 Joutel's Journal of La Salle's Last Voyage. Translated by Henry R. Stiles. J. McDonough, Albany.

Kelley, David B.

2012 The Belcher Phase: Sixteenth- and Seventeenth Century Caddo Occupation of the Red River Valley in Northwest Louisiana and Southwest Arkansas. In The Archaeology of the Caddo, edited by Timothy K. Perttula and Chester P. Walker, pp. 411-430. University of Nebraska Press, Lincoln.

Kenmotsu, Nancy A.

2005 Investigations at the Salt Well Slough, 41RR204, A Salt-Making Site in Red River County, Texas. Texas Historical Commission, Archaeological Reports Series No. 4. Austin.

Keslin, Richard O.

1964 Archaeological Implications on the Role of Salt as an Element of Cultural Diffusion. The Missouri Archaeologist 26. Columbia.

Lewis, Anna

1924 French Interests and Activities in Oklahoma. Chronicles of Oklahoma 2(3):253-262. 
McCrocklin, Claude

1985 Potter's Pond, 16WE76, A Caddo Salt and PotteryMaking Site. Field Notes 210:3-5. Arkansas Archaeological Society, Fayetteville.

Morris, John Miller

2003 First Arrivals: Coronado, Hank Smith, and the Old Springs of the Llano Estacado. In The Coronado Expedition: From the Distance of 460 Years, edited by Richard Flint and Shirley Cushing Flint, pp. 219-239. University of New Mexico Press, Albuquerque.

Muller, Jon

1984 Mississippian Specialization and Salt. American Antiquity 49(3):489-507.

Rollings, Willard H.

1995 The Osage: An Ethnohistorical Study of Hegemony on the Prairie-Plains. University of Missouri Press, Columbia and London.

Sibley, John

1922 A Report from Natchitoches in 1807, edited by Annie H. Abel. Museum of the American Indian, Heye Foundation, Indian Notes and Monographs, Miscellaneous Series 25:5-102.

Surrey, Nancy Maria

1916 The Commerce of Louisiana During the French Regime, 1699-1763. Studies in History, Economics, and Public Law, Vol. 71. Columbia University, New York.

Swanton, John R.

1911 Indian Tribes of the Lower Mississippi Valley and Adjacent Gulf Coast. Bureau of American Ethnology, Bulletin No. 43, Smithsonian Institution, Washington, D.C.
1942 Source Material on the History and Ethnology of the Caddo Indians. Bureau of American Ethnology, Bulletin No. 132. Smithsonian Institution, Washington, D.C.

Usner, Daniel H., Jr.

1992 Indians, Settlers, and Slaves in a Frontier Exchange Economy: The Lower Mississippi Valley Before 1783. The University of North Carolina Press, Chapel Hill and London.

Veatch, Arthur C.

1902 The Salines of North Louisiana. In A Report on the Geology of Louisiana, by Gilbert D. Harris, Arthur C. Veatch, and Jov. A. A. Pacheco, pp. 47-100. Special Report No. 2. Louisiana State Experiment Station, Geology, and Agriculture, Baton Rouge.

Walker, Winslow M.

1935 A Caddo Burial Site at Natchitoches, Louisiana. Smithsonian Miscellaneous Collections 94(14). Smithsonian Institution, Washington, D.C.

Weber, David J.

1992 The Spanish Frontier in North America. Yale University Press, New Haven and London.

Wissler, Clark

1914 The Influence of the Horse in the Development of Plains Culture. American Anthropologist 16(1):125. 